\author{
Review Article \\ www.ijrap.net
}

\title{
CONCEPTUAL STUDY ON THE ETIOPATHOGENESIS AND AHARAJA NIDANAS IN VISHVACHI
} Asha Rani V ${ }^{1 *}$, Rashmi B. $\mathrm{M}^{2}$

${ }^{1}$ PG Scholar, Department of PG studies in Roganidana, Government Ayurvedic Medical College and Hospital, Bengaluru, Karnataka, India

${ }^{2}$ Assistant Professor, Department of PG studies in Roganidana, Government Ayurvedic Medical College and Hospital, Bengaluru, Karnataka, India

Received on: 30/01/19 Accepted on: 25/02/19

\begin{abstract}
*Corresponding author
E-mail: asha.rani.v92@gmail.com
\end{abstract}

DOI: 10.7897/2277-4343.100232

\begin{abstract}
Ayurveda is the most supreme science of medicine as it deals with all aspects of life, particularly of human beings. It talks about both health and diseased condition and its preventive aspects. Vishvachi is one among Vatavyadhi and has a close resemblance with the signs and symptoms of Cervical Radiculopathy. The lakshanas of Vishvachi is all alone mentioned in classics where in the nidana, purvarupa, samprapti must be considered from the light of samanya vatavyadhi. As a result of urbanization, we most commonly witness people often going for long drives, doing late night jobs, working in computers excessively. On the counterpart daily wage laborers, some occupational postures like in teachers, coolies, drivers, tailors are victims of cervical radiculopathy, are the commonest causes of neck pain. Ayurveda gives first importance to prevention of disease through nidana parivarjana (avoiding etiological factors). Hence here this is an attempt to explain the Nidanapanchakas of the disease Vishvachi and its possible Aharaja nidanas (dietetic etiological factors).
\end{abstract}

Keywords: Vata vyadhi, Cervical radiculopathy, Visvachi, Samanya vata vyadhi.

\section{INTRODUCTION}

As per Aristotle, "The Hand is the organ of organs, the active agent of the passive powers of the entire system ${ }^{1}$ ". Vishvachi is one among the vatavyadhi ${ }^{2}$ affecting the hand that causes bahuchesta apaharana (loss of movement of upper limb), shoola (pain) from bahuprushta (arms and shoulder) region to anguli (fingers). Here the kandaras arising from the back of the shoulders and running up to the fingers are affected impairing the adduction, abduction and other functions of the arm.

Cervical Radiculopathy (radix $=$ root) or Cervical spondylotic radiculopathy ${ }^{3}$ shows compression of a nerve root which occurs when a disc prolapsed laterally which is due to osteophytic encroachment of the inter-vertebral foramina presenting the features of neck pain that may radiate in the distribution of the affected nerve root can be paralleled with vishvachi.

It is commonly seen in old age, but in present scenario also seen in young and middle-aged people. The annual incidence of cervical radicular symptoms to be 83.2 per 100000 populations and its prevalence is most significant between 50-54-year age group 4 .

It is most prevalent among the farmers and labor class who lift heavy objects, push or pull heavy objects, operate vibrating equipment, some occupational odd postures, such as tailors, drivers, and daily wage workers who involve in strenuous activities. And today as a result of modernization the most common trend we witness in this busy world is: people often going for long drives in vehicles, working for long hours in front of computers, night outs in call centers ultimately resulting with early or late victims of Vishvachi (Cervical radiculopathy), one of the commonest causes of neck pain.

\section{Nirukti according to different Acharyas}

"Viswam anchati iti vishvachi": It is derived from the root word with 'vishva' as dhatu and 'anch' as pratyaya. Vishwa means entire / whole all pervading. Anch means turned to directed towards / to move / to wander about. Thus 'Vishvachi' literally means to spread throughout ${ }^{5}$. According to Shabdakalpadruma (vol.4) - it is mentioned as "Bahu roga vishesha". In Agni Purana one of the names of Apsaras is Vishvachi. According to the Sanskrit-English Dictionary by M. Monier Williams, which means the Paralysis of Arms and the back.

\section{Types of Vishvachi}

According to Nyayachandrika vyakhya of Sushrutha Samhita, this disease can occur in two types ${ }^{6}$ : Vataja type is pain predominant. Vatakaphaja type presents with numbness, weakness and loss of appetite along with Vataja Vishvachi features.

\section{Nidana Panchakas of Vishvachi}

\section{Nidana}

All the etiological factors of Vatavyadhi are taken as nidana of Vishvachi and the same is classified as:

- Aharaja (Dietetic factor)

- Viharaja (Behavioral factor)

- Manasika (Psychic factor) 


\section{Aharaja Nidana}

The foods which we consume like rooksha ahara (un unctuous food), sheeta ahara (cold foods), laghu ahara (light foods), ati tikta rasa sevana (excessive use of bitter taste foods), ati kashaya rasa sevana (astringent taste fods), ati katu rasa sevana (pungent taste foods), alpamatraahara (less quantity food), vishamashana (consuming less or more food), adhyashana (eating before digestion of previously consumed food), pramitashana (intake of nutrition deficient food or consuming very less food), are contributory factors.

\section{Viharaja Nidana}

The improper activities like atiprajagarana (excessive awakening), ativyayama (excessive exercise), ativyavaya (excessive sexual intercourse), vega dharana (suppression of natural urges), vega udeerana (premature initiation of natural urges), dukhashayya (improper sleeping posture), dukha asana (uncomfortable postures) are the contributory factors.

\section{ManasikaNidana}

Various mental faculties such as kama (desire), chinta (worry), krodha (anger), shoka (sorrow), bhaya (fear) causes vataprakopa.

\section{Samprapti}

\section{Poorvarupa}

The manifestation of symptoms before the actual manifestation of disease is called as poorvarupa. No specific poorvarupa of vatavyadhi has been mentioned in our classics but is clearly mentioned that Avyakta Lakshanas are the poorvarupa of Vatvyadhi. In Chakrapani commentary he mentions that avyakta means 'AlpaVyaktam'.

Hence before the actual manifestation of the disease alpa ruk, alpa stabdhata, ishat suptata and shrama in bahu after a long period of strain full work can be considered as a stage of Vishvachi poorvarupa ${ }^{7}$.

\section{Rupa}

In the commentary by Acharya Dalhana, he says 'further the disease resembles Gridhrasi'. Lakshanas like Dehasyapipravakrta (scoliosis), janu uru sandhi sphurana (pulsations in knee and thigh) are specially categorized as vatika gridhrasi lakshanas. And this can be considered even for vishvachi but the difference being site and bahu karma kshaya ${ }^{8,9}$.

\section{Upashaya}

Upashaya for Vishvachi is the same as that of any other vata vikara particularly such as Sarpi (Ghee), Vasa (Muscle fat) and Majja (Bone marrow) ${ }^{10}$. Involvement of dosha, dushya, and mode of samprapti i.e., margarodhaja or dhatu kshayajanya is understood by upashaya (pacifying factors) and anupashaya (provoking factors).

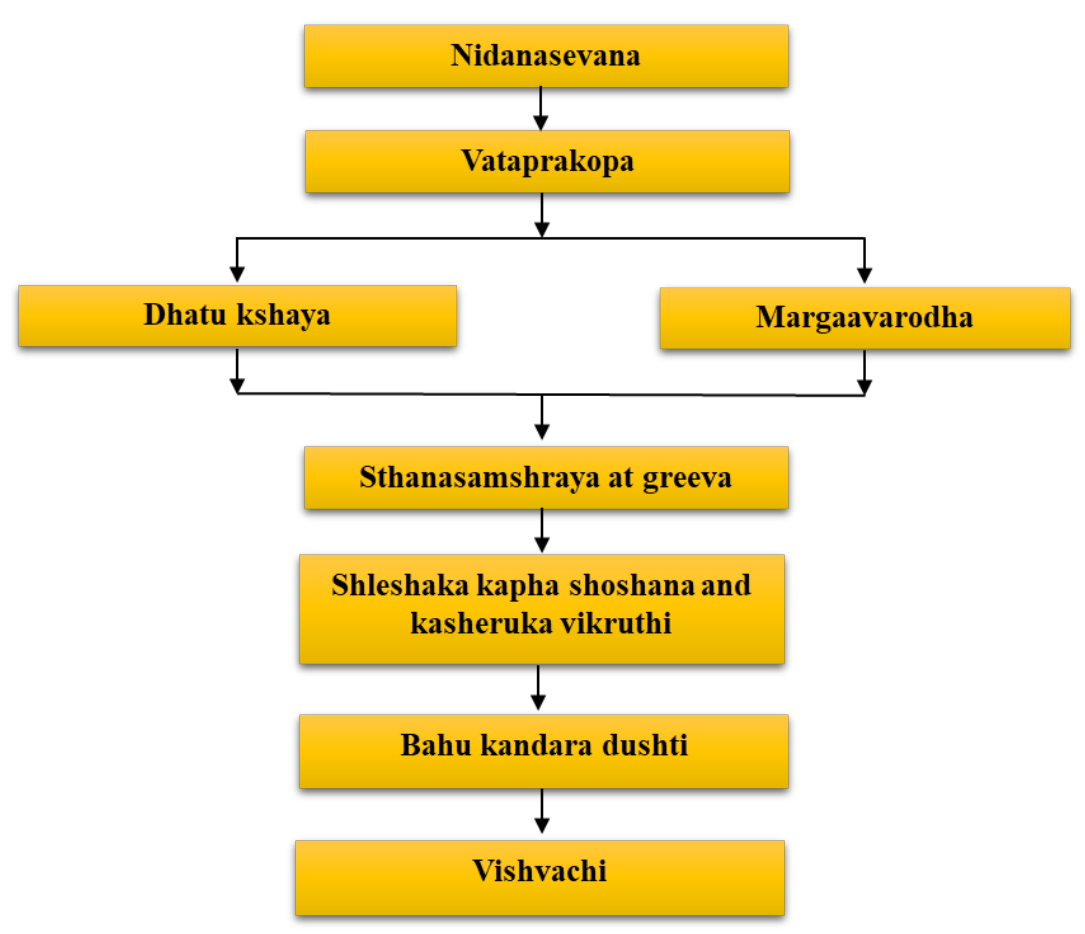

Figure 1: Samprapti of Vishvachi

\section{Aharaja Hetu in Vishvachi}

The word 'Nidana' (etiology) is used in Ayurveda classics in a broad sense. This word is derived from Sanskrit Dhatu 'Ni' which carries the meaning to determine (Ni-Nishchaya Deeyate Jnanam). This word either refers to eito-pathogenesis of disease in general or the etiology of the illness ${ }^{11}$. Since Vishvachi is regarded as Vatyavyadhi of Nanatmaja type, the factors that precipitate prakopa of vata can also be taken as the Nidana (etiology) for disease Vishvachi (Cervical radiculopathy). Dietetic factors play major role as causative factors for the pathogenicity of various diseases; henceforth will be explaining 
in detail regarding possible Aharaja nidanas (dietetic factors) responsible for the pathogenicity of the disease Vishvachi (Cervical radiculopathy).

\section{Aharaja hetu}

The causative dietetic factors included under this group have been again subdivided into the following 7 groups:

\section{Dravyatah}

In this group all the aharaja dravyas (dietetic factors) responsible for vataprakopa has been included.

\section{Gunatah}

This group includes the ahara dravyas (dietetic factors) possessing gunas (quality) like Ruksha (dry), Sheeta (cold) and so on.

\section{Rasatah}

The ahara dravyas (dietetic factors) possessing various tastes like Katu (pungent), Tikta (bitter) and Kashaya (astringent) are responsible for vata dosha prakopa.

\section{Karmatah}

Excessive use of vishtambhi ahara (food which is cause for constipation) leads to prakopa of vata.

\section{Veeryatah}

Ahara Dravyas (dietetic factors) possessing sheeta veerya (cold potency)cause prakopa of vata.

\section{Matratah}

The quantity of ahara (food) can be considered.

\section{Kalatah}

Vataprakopa occurs at the end of digestion (bhuktejeeryatibhojane cha). The following haraja hetus (dietetic causes) are taken from various classical texts Charaka (C.S), Sushrutauttartantra (S.U), Astanga sangraha (A.S), Astangahrudaya (A.H), Bhava Prakasha (B.P).

Table 1: Aharaja Hetu (dietetic causes)

\begin{tabular}{|c|c|c|c|c|c|}
\hline & C.S & S.U & A.S & A.H & B.P \\
\hline Adhaki (Cajanus cajan) & - & + & - & - & - \\
\hline Bisa (Nelumbo nucifera) & - & + & + & - & - \\
\hline Chanaka (Cicer arietinum) & - & - & + & - & - \\
\hline Chirabhata (Cucumis melo) & - & - & + & - & - \\
\hline Harenu (Pisum sativum) & - & + & - & - & - \\
\hline Jambhava (Eugenia jambolana) & - & - & + & - & - \\
\hline Kalaya (Lathyrus sativus) & - & + & + & - & - \\
\hline Karira (Capparis decidua) & - & - & + & - & - \\
\hline Kalinga (Holarrhena antidysenterica) & - & - & + & - & - \\
\hline Koradusha (Paspalum scorbiculatum) & - & + & - & - & - \\
\hline Masura (Lens culinaris) & - & + & - & - & - \\
\hline Mudga (Phaseolus mungo) & - & + & - & - & - \\
\hline Nishpava (Dolichos lablab) & - & + & - & - & - \\
\hline Neevara (Hygroryza aristata) & - & + & + & - & - \\
\hline Shaluka (Nelumbium speciosum) & - & - & + & - & - \\
\hline Shushkashaka (Dry vegetables) & - & + & - & - & - \\
\hline Shyamaka (Setaria italica) & - & + & - & - & - \\
\hline Tinduka (Diospyros tomentosa) & - & - & + & - & - \\
\hline Trunadhanya (Grassy grains sp.) & - & - & + & - & - \\
\hline Tumba (Lagenaria vulgaris) & - & - & + & - & - \\
\hline Uddalaka (A variety of Paspalum scorbiculatum) & - & + & - & - & - \\
\hline Varaka (Carthamus tinctorius) & - & + & - & - & - \\
\hline Viroodhaka (Germinated seeds) & - & - & + & - & - \\
\hline
\end{tabular}

Gunataha

\begin{tabular}{|l|c|c|c|c|c|}
\hline Rukshanna (non unctous diet) & + & + & + & + & + \\
\hline Laghvanna (Light diet) & - & + & + & - & - \\
\hline Gurvanna (Heavy diet) & - & - & + & + & - \\
\hline Sheetanna (Cold diet) & + & - & + & - & - \\
\hline
\end{tabular}

Rasataha

\begin{tabular}{|l|c|c|c|c|c|}
\hline Kashayanna (Astringent taste) & - & + & + & + & + \\
\hline Katvanna (Acidic taste) & - & + & + & + & + \\
\hline Tiktanna (Bitter taste) & - & + & + & + & + \\
\hline
\end{tabular}

Kalataha

\begin{tabular}{|c|c|c|c|c|c|}
\hline Adhyasana (Eating before digestion of previous food) & - & + & - & - & - \\
\hline Jeernanta (After digestion) & - & + & + & + & + \\
\hline Pramitashana (Taking less quantity food or less nutritious food) & - & - & + & + & + \\
\hline
\end{tabular}


Matrataha

\begin{tabular}{|c|c|c|c|c|c|}
\hline Abhojana (Fasting) & + & + & - & - & + \\
\hline Alpashana (Less intake of food) & + & - & + & + & - \\
\hline Vishamashana (Intake of food in improper time irrespective of quantity) & - & + & - & - & - \\
\hline
\end{tabular}

Karmataha

\begin{tabular}{|l|l|l|l|l|l|}
\hline Vishtambhi (Diet cause for constipation) & - & - & + & - & - \\
\hline
\end{tabular}

Veeryataha

\begin{tabular}{|l|l|l|l|l|l|}
\hline Sheeta (Cold potency) & - & - & - & - & - \\
\hline
\end{tabular}

Table 2: Summary chart of Aharaja Nidanas

\begin{tabular}{|l|c|c|c|c|c|c|c|}
\hline \multicolumn{1}{|c|}{ Ayurveda Samhita } & Dravya & Guna & Rasa & Karma & Veerya & Matra & Kala \\
\hline Charaka & 0 & 2 & 0 & 0 & 0 & 2 & 0 \\
\hline Sushruta & 13 & 2 & 3 & 0 & 0 & 2 & 2 \\
\hline Ashtanagasangraha & 12 & 4 & 3 & 1 & 0 & 1 & 2 \\
\hline Ashtangahridaya & 0 & 2 & 3 & 0 & 0 & 1 & 2 \\
\hline Bahavaprakash & 0 & 2 & 3 & 0 & 0 & 1 & 2 \\
\hline
\end{tabular}

\section{DISCUSSION}

Present day lifestyle has led to many diseases which though doesn't kill the person but hampers the day-to-day life. One of such disease is Vishvachi, affecting the upper limbs. Vishvachi is one of the most common types of Vatavyadhi found in clinical practice, in which the prakupitha vata affects kandara of bahu. It is a disorder which is prevalent in the most active period of life. Being a shoola pradhana nanatmaja vyadhi, it deprives the patient's ability to perform movements of upper limb, which in turn makes them unable to carry their routine work.

\section{CONCLUSION}

Vatavyadhis are the disorders caused solely by vitiated vata dosha; also called as vataja nanatmaja vyadhis. They are mostly endogenous (nija roga) disorders of specific type caused by solely aggravated vata dosha on its own accord (vatakara nidana) and not in combination with other doshas. As per the above references the above mentioned aharaja nidanas can be taken as the possible nidanas for the disease Vishvachi.

\section{REFERENCES}

1. H Edwards, A Skeptics's Guide to the New Age, Investigator Magazine [monograph on the Internet].http://ed5015. tripod.com/PaPalmistry93.htm

2. Yadavji Trikamji Acharya, Vatavyadhi nidana, Sushrutha samhita, Reprint ed; 2010. p. 268.

3. Chirstopher Haslett, Edvin R Chilvers, Nicholas A Boon, Nicki R. Colledge Davidsons principles and practice of medicine, $19^{\text {th }}$ edition, p. 1190
4. Frank M. Painter DC, Radiculopathy and Chiropractic, [monograph on the Internet] https://chiro.org/LINKS/ Radiculopathy.shtml

5. Dr. Dominic Puthoor, MS (Ortho), Amala Institute of Medical Sciences, Thrissur, Proceedings of the Ayurveda seminar on Viswachi, [monograph on the Internet] www.amalaayurveda.org/seminars/Cervical_Spondylosis.pd $\mathrm{f}$

6. Dr. Dominic Puthoor, MS (Ortho), Amala Institute of Medical Sciences, Thrissur, Proceedings of the Ayurveda seminar on Viswachi, [monograph on the Internet] www.amalaayurveda.org/seminars/Cervical_Spondylosis.pd $\mathrm{f}$

7. Yadavji Trikamji Acharya, Jwara nidanam, Charaka Samhita, Commentary by Chakrapani Dutta, Chaukambha surabharthi prakashana, Varanasi, U.P, $4^{\text {th }}$ edition; 2000. p. 194.

8. Pt Brahma Shankar Mishra, Vata vyadhi adhikara, Bhavaprakasha nighantu, Vol-1, $11^{\text {th }}$ edition; 2007. p. 236.

9. Sri Brahma Shankara Shastri, Vata vyadhi nidanam, Yogaratnakara, Vidyotini Tika, Edition; 2010. p. 411.

10. Yadavji Trikamji Acharya edited, Charaka samhita with Ayurveda Deepika commentary, Chikitsa sthana, Vatavyadhi chikitsa, edition: reprint; 2004. p. 621.

11. Brahmanand Tripathi, Chapter: Pancha nidana lakshana, Madhava Nidana, Vol-1, Chaukambha surabharthi prakashana, Varanasi, U.P; 2008. p. 17.

\section{Cite this article as:}

Asha Rani V and Rashmi B. M. Conceptual study on the etiopathogenesis and Aharaja nidanas in Vishvachi. Int. J. Res. Ayurveda Pharm. 2019; 10(2):33-36 http://dx.doi.org/ $10.7897 / 2277-4343.100232$ the site content and articles published. The views expressed in articles by our contributing authors are not necessarily those of IJRAP editor or editorial board members. 